\title{
Effect of leaching residual methyl methacrylate concentrations on in vitro cytotoxicity of heat polymerized denture base acrylic resin processed with different polymerization cycles
}

\author{
Canan BURAL ${ }^{1}$, Esin AKTAŞ², Günnur DENIZ ${ }^{3}$, Yeşim ÜNLÜÇERÇI ${ }^{4}$, Gülsen BAYRAKTAR ${ }^{5}$
}

1- DDS, PhD, Assistant Professor, Department Prosthodontics, Istanbul University, Faculty of Dentistry, Istanbul, Turkey.

2- MsC, PhD, Assistant Professor, Department of Immunology, Institute of Experimental Medicine, Istanbul University, Istanbul, Turkey.

3- MsC, PhD, Professor, Department of Immunology, Institute of Experimental Medicine, Istanbul University, Istanbul, Turkey.

4- DMD, Professor, Department of Biochemistry, Istanbul Medical Faculty, Istanbul University, Istanbul, Turkey.

5- DDS, PhD, Professor, Department of Removable Prosthodontics Istanbul University, Faculty of Dentistry, Istanbul, Turkey.

Corresponding address: Dr. Canan Bural - Istanbul University, Faculty of Dentistry - Department of Removable Prosthodontics - Capa, 34390 - Istanbul - Turkey - Phone: +902124142020 (ext: 30256) - Fax: +902125253585 - e-mail: cbural@istanbul.edu.tr

Received: July 21, 2009 - Modification: March 31, 2010 - Accepted: May 25, 2010

\section{ABSTRACT}

$\mathrm{O}$ bjectives: Residual methyl methacrylate (MMA) may leach from the acrylic resin denture bases and have adverse effects on the oral mucosa. This in vitro study evaluated and correlated the effect of the leaching residual MMA concentrations ([MMA $]_{\mathrm{r}}$ ) on in vitro cytotoxicity of L-929 fibroblasts. Material and Methods: A total of 144 heat-polymerized acrylic resin specimens were fabricated using 4 different polymerization cycles: (1) at $74^{\circ} \mathrm{C}$ for $9 \mathrm{~h}$, (2) at $74^{\circ} \mathrm{C}$ for $9 \mathrm{~h}$ and terminal boiling (at $100^{\circ} \mathrm{C}$ ) for $30 \mathrm{~min}$, (3) at $74{ }^{\circ} \mathrm{C}$ for $9 \mathrm{~h}$ and terminal boiling for $3 \mathrm{~h},(4)$ at $74^{\circ} \mathrm{C}$ for $30 \mathrm{~min}$ and terminal boiling for $30 \mathrm{~min}$. Specimens were eluted in a complete cell culture medium at $37^{\circ} \mathrm{C}$ for $1,2,5$ and 7 days. $[\mathrm{MMA}]_{\mathrm{r}}$ in eluates was measured using high-performance liquid chromatography. In vitro cytotoxicity of eluates on L-929 fibroblasts was evaluated by means of cell proliferation using a tetrazolium salt XTT (sodium 3' -[1-phenyl-aminocarbonyl)-3,4-tetrazolium]bis(4methoxy-6-nitro)benzenesulphonic acid) assay. Differences in [MMA $]_{\text {r }}$ of eluates and cell proliferation values between polymerization cycles were statistically analyzed by KruskalWallis, Friedman and Dunn's multiple comparison tests. The correlation between [MMA] of eluates and cell proliferation was analyzed by Pearson's correlation test $(p<0.05)$. Results: $[M M A]_{r}$ was significantly $(p \leq 0.001)$ higher in eluates of specimens polymerized with cycle without terminal boiling after elution of 1 and 2 days. Cell proliferation values for all cycles were significantly $(p<0.01)$ lower in eluates of 1 day than those of 2 days. The correlation between $[M M A]_{r}$ and cell proliferation values was negative after all elution periods, showing significance $(p<0.05)$ for elution of 1 and 2 days. MMA continued to leach from acrylic resin throughout 7 days and leaching concentrations markedly reduced after elution of 1 and 2 days. Conclusion: Due to reduction of leaching residual MMA concentrations, use of terminal boiling in the polymerization process for at least $30 \mathrm{~min}$ and water storage of the heat-polymerized denture bases for at least 1 to 2 days before denture delivery is clinically recommended for minimizing the residual MMA and possible cytotoxic effects.

Key words: Acrylic resins. Denture bases. Methylmethacrylate. Cytotoxicity. Cell proliferation. Chromatography, high pressure liquid. 


\section{INTRODUCTION}

Heat-polymerization is the most widely used method of polymerization for acrylic resin denture base fabrication and usually is accomplished in a heated water-bath ${ }^{10,12,26}$.

The nature and duration of the conditions to which the molded acrylic resin subjected is described as the polymerization cycle ${ }^{14,26}$. The conventional method of polymerization cycle is a long, slow-temperature water-bath polymerization where the heat-polymerization of acrylic resin is processed for $9 \mathrm{~h}$ at $74^{\circ} \mathrm{C}^{26}$. There are also postpolymerization cycles such as terminal boiling at $100^{\circ} \mathrm{C}$ for durations of $30 \mathrm{~min}$ (short-term) or longer than $1 \mathrm{~h}$ (long-term) ${ }^{10,12,14,32}$. Furthermore, it has been reported that total polymerization time shorter than $2 \mathrm{~h}$ is widely preferred than the long polymerization cycles $^{3}$.

Although there has been several reported variations of polymerization temperature and time, the conversion of monomer is not complete and this might result in unreacted, residual monomer in the denture base acrylic resin ${ }^{2-5,10,12,14,25}$. Methyl methacrylate (MMA) was the predominant residual monomer in the acrylic resin ${ }^{32}$. In addition, it has been stated that the residual MMA content might change due to polymerization method $4,5,31$ and cycle $10,12,14,25,32$.

Denture base is in continuous contact with the great part of the oral mucosa. It is important to evaluate the effect of the residual monomer, which has been shown to leach into water ${ }^{21,31,32}$, saliva2,4,30 or artificial saliva ${ }^{20}$, on the oral mucosa that is adjacent to the denture base. Leaching residual monomer have been suggested as potentially high enough to cause irritation of oral mucosa, irritation or even an allergic reaction. This might especially be important for patients with infected, inflamed or lacerated mucosa ${ }^{11,23}$.

In vitro cytotoxic effects of denture base acrylic resins have also been attributed to the leaching components ${ }^{4,8,15,17-19,22-24,30}$. Although there are a number of reports of in vitro cytotoxicity of denture base acrylic resins, which were processed with various polymerization methods and cycles ${ }^{8,11,16-19,22-24,30}$, there is no available study that correlated in vitro cytotoxicity and the leaching concentrations of residual MMA $\left([\mathrm{MMA}]_{\mathrm{r}}\right)$ of heatpolymerized denture base acrylic resin, processed with different polymerization cycles. The aims of the present study were to evaluate 1 ) $[\mathrm{MMA}]_{r}, 2$ ) in vitro cytotoxicity, 3) the correlation between the leaching $[\mathrm{MMA}]_{\mathrm{r}}$ and in vitro cytotoxicity of heatpolymerized specimens, polymerized with different polymerization cycles after elution in a cell culture medium for 1, 2, 5 and 7 days. The hypothesis was that terminal boiling would reduce the leaching
$[\mathrm{MMA}]_{\mathrm{r}}$ and in vitro cytotoxicity of heat-polymerized denture base acrylic resin.

\section{MATERIAL AND METHODS}

\section{Specimen preparation}

Stainless steel discs ( $1 \mathrm{~mm}$ thick $\times 10 \mathrm{~mm}$ diameter) $)^{22-24}$ were conventionally molded in Type II dental stone (Moldano, Heraus Kulzer, Germany) with a powder/liquid ratio of $100 \mathrm{~g} / 30 \mathrm{~mL}$ under aseptic conditions. Flasks were kept under hydraulic pressure (Kavo Elektrotechnisches Werk, GmBH, Allgäu, Germany) of 2 atm for 45 min.

Heat-polymerizing, PMMA based denture base acrylic resin (Meliodent Heat-cure Denture Base Material; Heraus Kulzer GmBH\&Co., Hanau, Germany) without cadmium was tested in the present study. Acrylic resin was mixed in accordance with manufacturers' recommendations, with a powder/liquid ratio of $23.4 \mathrm{~g} / 10 \mathrm{~mL}$ for $60 \mathrm{~s}$ at room temperature $\left(23 \pm 2^{\circ} \mathrm{C}\right)$. After $5 \mathrm{~min}$ of doughing time, unpolymerized resin was packed in molds and then flasks were kept under hydraulic pressure of 2 atm for $45 \mathrm{~min}$.

Heat-polymerization was performed in thermostatically controlled water bath (Kavo EWL Typ 5506; Kavo Elektronisches Werk) with 4 different polymerization cycles (Figure 1). After completion of the polymerization cycles, the flasks were cooled at room temperature $\left(23 \pm 2^{\circ} \mathrm{C}\right)$ for $2 \mathrm{~h}$. Specimens were transferred into sterile centrifuge tubes (TPP Centrifuge Tubes, Switzerland), containing $50 \mathrm{~mL}$ of distilled water at room temperature $\left(23 \pm 2^{\circ} \mathrm{C}\right)$ and then ultrasonically cleaned (Metu Elektromekanik; Ultrasonic Cleaner, Istanbul, Turkey) for $5 \min ^{16-19}$.

Thirty six $(n=36)$ acrylic resins specimens were fabricated for each polymerization cycle with a total of 144 specimens.

\section{Eluate preparation}

Complete cell culture medium without serum ${ }^{11}$ was used as elution medium. Eluates of specimens were prepared by placing 3 disks into a sterile vial with $9 \mathrm{~mL}^{11,17}$ of Dulbecco's modified eagle medium (DMEM)/ F-12 (Biological Industries, Haemek, Israel) supplemented with $1 \%$ antibiotics solution (100 IU/mL penicillin, $100 \mu \mathrm{g} / \mathrm{mL}$ streptomycin, 25 $\mu \mathrm{g} / \mathrm{mL}$ Amfoterisin-B; Biological Industries), $1 \%$ vitamin solution (MEM-Vitamins Solution 100X; Biological Industries), $2 \%$ non-essential amino acid solution (MEM-Eagle non-essential amino acid solution 100X; Biological Industries), and 1\% L-Glutamine (L-Glutamine Solution; 200 mM, Biological Industries). The DMEM was maintained at pH 7.3 by adding 25 mM HEPES (HEPES BUFFER; Biological Industries) ${ }^{7}$. The ratio of surface area of the discs to the volume of culture medium was $0,626 \mathrm{~cm}^{2} / \mathrm{mL}$ and was within the range $0.5-6.0$ 
$\mathrm{cm}^{2} / \mathrm{mL}$ as recommended by the International Standards Organization (ISO) 10993-513.

Specimens were eluted with complete cell culture medium at $37^{\circ} \mathrm{C}$ for $1,2,5$ and 7 days in a humidified atmosphere of $5 \% \mathrm{CO}_{2}, 95 \%$ air. After each elution period, the eluates were removed and the specimens were transferred into new vials and fresh cell culture medium. Cell culture media without acrylic resin specimens were also incubated to serve as negative controls ${ }^{11,16-19}$. Eluates were filtered for sterilization and $10 \%$ fetal calf serum (FCS Heat-inactivated; Biological Industries) were added. Eluates were stored at $-20^{\circ} \mathrm{C}$ until the determination of the concentration of leaching residual MMA and in vitro cytotoxicity tests.

\section{Determination of leaching residual MMA concentration $\left([\mathrm{MMA}]_{\mathrm{r}}\right.$ ) \\ $[M M A]_{r}$ in eluates was determined using High} Performance Liquid Chromatography (HPLC) with the HPLC pump (Waters 600 E, Millford, MA, USA) equipped with a gradient controller (Waters Model 600), autosampler (Waters 717 plus), tunable UVVis detector (Waters 486) and a reversed phase C18 with stainless steel analytical column ( $\mu$ Bondapak $3.9 \times 300 \mathrm{~mm}, 10 \mu$ particle size, $125 \mathrm{~A}^{\circ}$ ).

The analysis was performed at room temperature $\left(23 \pm 2^{\circ} \mathrm{C}\right)$ under the following conditions: chromatographic grade methanol (Merck, KGaA, Darmstadt, Germany)/distilled water (1:1) mobile phase; $0.8 \mathrm{~mL} / \mathrm{min}$ flow rate and detection at 220 $\mathrm{nm}$.
Known serial concentrations of 1, 2, 3, 5 and 10 $\mu \mathrm{mol} / \mathrm{L}$ (standards) of MMA dissolved in methanol was analyzed and a calibration curve (Figure 2) was obtained using chromatographic MMA peak at retention time of 10.22 min (Figure 3 ).

Eluates were diluted with methanol $(1: 5 \mathrm{v} / \mathrm{v})$ and injected into column with $10 \mu \mathrm{L}$ volume. Peak area of each eluate was put into equation obtained from the calibration curve (Figure 2 ) and $[\mathrm{MMA}]_{\mathrm{r}}$ in each eluate was expressed as $\mu \mathrm{mol} / \mathrm{L}$.

Twenty-four chromatographic analyses for each polymerization cycle and 6 for each elution period with a total of 96 analyses were performed.

\section{Cell culture}

L-929 murine fibroblasts (American Type Culture Collection, CCL 1 fibroblast, NCTC clone 929) were used in the study. Cells were cultured in $75 \mathrm{~cm}^{2}$ culture flasks (TPP, Tissue Culture Dish, Switzerland) with the complete cell culture medium described above and incubated at $37^{\circ} \mathrm{C}$ in a humidified atmosphere of $5 \% \mathrm{CO}_{2}, 95 \%$ air.

\section{Cell proliferation}

Cell proliferation was assessed using a colorimetric assay system (XTT Cell Proliferation Kit; Biological Industries) which measures the reduction of a tetrazolium component, XTT (sodium 3 ' -[1-phenyl-aminocarbonyl)-3,4-tetrazolium] bis(4-methoxy-6-nitro)benzenesulphonic acid) into soluble formazan product by the mitochondria of viable cells. This assay kit contains a XTT reagent

\begin{tabular}{|c|c|c|c|c|}
\hline Code & \multicolumn{2}{|c|}{ Polymerization cycle } & \\
\hline $\mathrm{H} 1$ & at $74^{\circ} \mathrm{C}$, for $9 \mathrm{~h}$ & & & (Conventional) \\
\hline $\mathrm{H} 2$ & at $74^{\circ} \mathrm{C}$, for $9 \mathrm{~h}$ & + & at $100^{\circ} \mathrm{C}$, for $30 \mathrm{~min}$ & (Short-term terminal boil) \\
\hline $\mathrm{H} 3$ & at $74^{\circ} \mathrm{C}$, for $9 \mathrm{~h}$ & + & at $100^{\circ} \mathrm{C}$, for $3 \mathrm{~h}$ & (Long-term terminal boil) \\
\hline $\mathrm{H}^{\mathrm{a}}$ & at $74^{\circ} \mathrm{C}$, for $30 \mathrm{~min}$ & + & at $100^{\circ} \mathrm{C}$, for $30 \mathrm{~min}$ & (Short-term polymerization) \\
\hline
\end{tabular}

a recommended polymerization cycle by the manufacturer

Figure 1- Polymerization cycles used

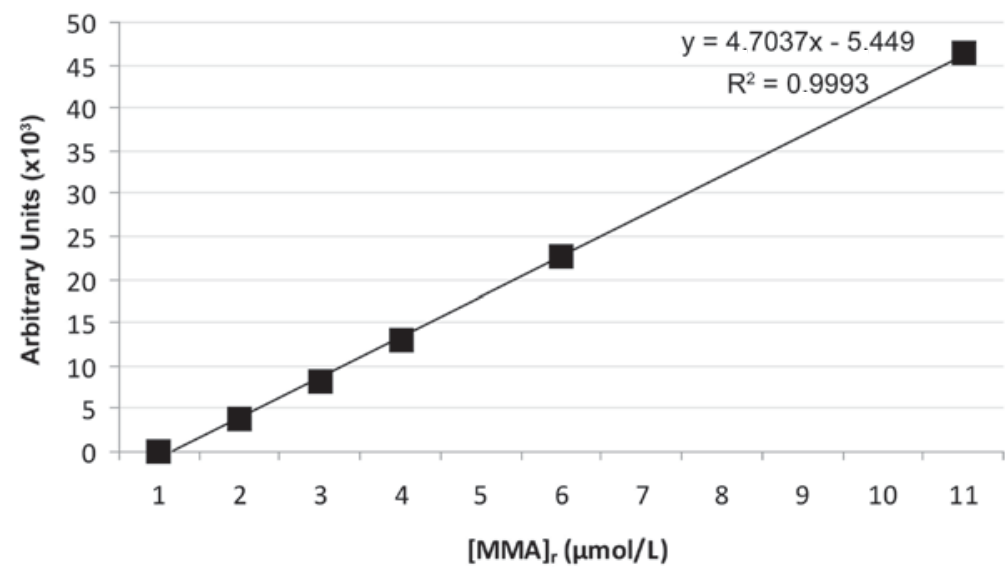

Figure 2- Standard calibration curve for methyl methacrylate (MMA) 


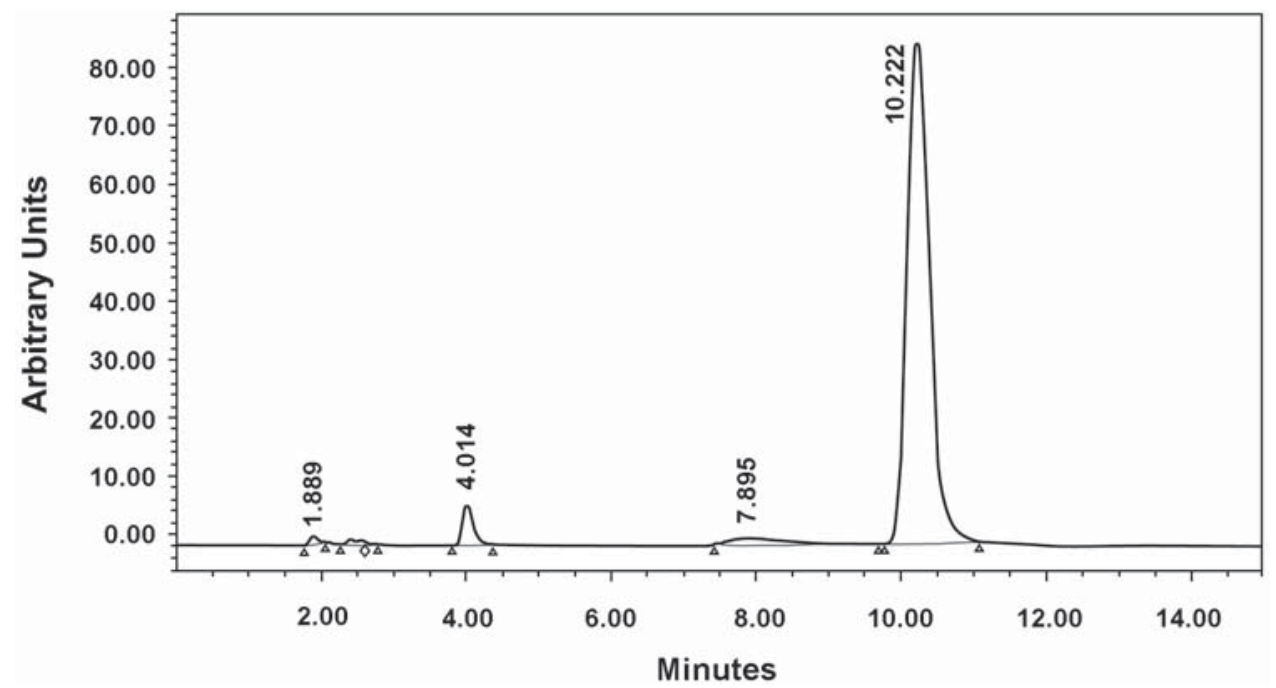

Figure 3- High performance liquid cromatography chromatogram of methyl methacrylate (MMA) and characteristic peak at approximately 10.22 min of retention time.

and an activation solution. $5 \times 10^{3}$ cells were plated in each well of 96 well-plates and incubated at $37{ }^{\circ} \mathrm{C}$ in a humidified atmosphere of $5 \% \mathrm{CO}_{2}, 95 \%$ air for 24 h. $100 \mu \mathrm{L}$ of eluates were added to each well and further incubated for $24 \mathrm{~h}^{7,19} .5 \mathrm{~mL}$ of XTT reagent were mixed with $0.1 \mathrm{~mL}$ activation solution in accordance with manufacturer's instructions to obtain a solution which will react with cells. $50 \mu \mathrm{L}$ of reaction solution were added to each well and incubated at $37^{\circ} \mathrm{C}$ in a humidified atmosphere of 5\% $\mathrm{CO}_{2}, 95 \%$ air for $2 \mathrm{~h}$. Twenty-four cell proliferation measurements for each polymerization cycle and six for each elution period with a total of 96 measurements were performed.

After incubation, colorimetric absorbance was measured at $450 \mathrm{~nm}$ (reference wavelength at $670 \mathrm{~nm}$ ) using a microtiter plate reader (Universal Microplate Reader ELX 800; Bio-Tek Instruments Inc., Winooski, VT, USA). Cell proliferation was expressed as a percentage of negative controls ${ }^{7,11,16-19}$.

Data were analyzed statistically using GraphPad Prisma Version 3 (San Diego, California, USA) $[\mathrm{MMA}]_{\mathrm{r}}$ and cell proliferation values between the polymerization cycles were analyzed with KruskalWallis test and the change in $[\mathrm{MMA}]_{\mathrm{r}}$ and cell proliferation values within the cycles were analyzed with Friedman tests. Post-hoc comparisons were performed by Dunn's multiple-comparisons test. The correlation between [MMA] in eluates and cell proliferation values were analyzed by Pearson's correlation test at significance level of 0.05 .

\section{RESULTS}

\section{Leaching [MMA]}

Mean and standard deviation values of $[\mathrm{MMA}]_{\mathrm{r}}$ of each polymerization cycle after elution of $1,2,5$ and 7 days are presented in Table 1 . For elution of 1 and 2 days, leached [MMA] $]_{r}$ of long-term terminal boiling cycle $(\mathrm{H} 3)$ was significantly $(p \leq 0.001)$ lower than polymerization cycles with no terminal boiling (H1) and short-term polymerization with short-term terminal boiling (H4). For elution of 5 and 7 days, leached $[\mathrm{MMA}]_{\mathrm{r}}$ of short-term terminal boiling cycle $(\mathrm{H} 2)$ was significantly lower than the cycles with no terminal boiling $(\mathrm{H} 1)(\mathrm{p} \leq 0.05)$ and long-term terminal boiling cycle $(\mathrm{H} 3)(\mathrm{p} \leq 0.05)$, respectively. Leached $[M M A]_{r}$ reduced significantly $(p<0.01)$ for polymerization cycle with no terminal boiling $(\mathrm{H} 1)$ between elution of 1 and 2 days and increased significantly $(p<0.05)$ in long-term terminal boiling cycle (H3) between elution of 2 and 7 days.

\section{Cell proliferation}

Mean and standard deviation of cell proliferation values of each polymerization cycle after elution of specimens for 1, 2, 5 and 7 days are shown in Table 2. For elution of 1 and 2 days, cell proliferation values of long-term terminal boiling cycle (H3) were significantly higher than cycles with no terminal boiling $(\mathrm{H} 1)(\mathrm{p}<0.01)$ and short-term polymerization with short-term terminal boiling (H4) $(p<0.05)$. Cell proliferation values changed significantly $(p<0.05)$ only in long-term terminal boiling cycle $(\mathrm{H} 3)$ with an increase between elution of 2 and 7 days.

The correlation between leached $[\mathrm{MMA}]_{\mathrm{r}}$ and cell proliferation values was negative after elution of 1 , 2,5 and 7 days. The correlation was statistically significant at elution of 1 day $(r=-0.573, p<0.01)$ and 2 days $(r=-0.491, p \leq 0.05)$. The correlation was also negative with no statistically significance at elution of 5 days $(r=-0.116, p>0.05)$ and 7 days $(r=-0.339, \mathrm{p}>0.05)$. 
Table 1- Mean residual \pm standard deviation methyl methacrylate [MMA], values at the end of days 1, 2, 5 and 7 of elution. The same letters indicate the statistically significant difference between cycles $(p \leq 0.05)$

\begin{tabular}{ccccc}
\hline Cycle & \multicolumn{4}{c}{ Elution $(\mu \mathrm{mol} / \mathrm{L})$} \\
\hline Day 1 & Day 2 & Day 5 & Day 7 \\
\hline H2 & $6.45 \pm 2.27^{\mathrm{a}, \mathrm{e}}$ & $3.23 \pm 1.16^{\mathrm{b}}$ & $3.41 \pm 1.04^{\mathrm{c}}$ & $4.04 \pm 1.19$ \\
$\mathrm{H} 3$ & $2.29 \pm 0.89$ & $1.69 \pm 0.55$ & $2.02 \pm 3.66^{\mathrm{c}}$ & $2.38 \pm 2.02^{\mathrm{d}}$ \\
$\mathrm{H} 4$ & $0.92 \pm 0.40^{\mathrm{a}}$ & $0.71 \pm 0.39^{\mathrm{b}, \mathrm{f}}$ & $2.66 \pm 3.62$ & $5.87 \pm 2.56^{\mathrm{d}, \mathrm{f}}$ \\
\hline
\end{tabular}

Table 2- Mean cell proliferation (\%) at the end of days 1, 2, 5 and 7 of elution. The same letters indicate the statistically significant difference between cycles $(p \leq 0.05)$

\begin{tabular}{ccccc}
\hline Cycle & \multicolumn{3}{c}{ Elution } & Day 7 \\
\hline D1 & $67.03 \pm 3.18^{\mathrm{a}}$ & $74.26 \pm 8.7$ & Day 5 & $72.26 \pm 6.13$ \\
$\mathrm{H} 2$ & $73.67 \pm 7.99$ & $84.56 \pm 5.71$ & $82.88 \pm 10.36$ & $72.73 \pm 9.96$ \\
$\mathrm{H} 3$ & $84.67 \pm 9.17^{\mathrm{a}}$ & $87.31 \pm 15.3^{\mathrm{b}}$ & $75.2 \pm 10.63$ & $66.84 \pm 6.56^{\mathrm{b}}$ \\
$\mathrm{H} 4$ & $72.99 \pm 4.23^{\mathrm{a}}$ & $75.04 \pm 1.96$ & $70.77 \pm 4.04$ & $71.29 \pm 2.84$ \\
\hline
\end{tabular}

\section{DISCUSSION}

As far as the existing scientific data on in vitro cytotoxicity of denture base materials are concerned, there is no available study that identifies or quantifies the leaching component in eluates of test specimens. This study showed and quantified that residual MMA leached into eluates. It was observed in this study that in vitro cytotoxicity changed depending on the leached [MMA]. In other words, increased [MMA] $]_{r}$ in the eluates produced reduced cell proliferation, thus increasing in vitro cytotoxicity. The hypothesis of this study was accepted, since terminal boiling reduced the leaching of $[\mathrm{MMA}]_{r^{\prime}}$ which in turn decreased the in vitro cytotoxic effects of heat-polymerized denture base resin.

Salivary concentrations of substances might diffuse from denture base acrylic resin ${ }^{2,4,20,21,30,32}$ and show cytotoxic effects ${ }^{22}$, depending on the time and the refreshing saliva. At the end of each elution period, eluates were collected and the tubes were re-filled with fresh culture medium ${ }^{11,22}$. This in vitro experimental design was preferred to simulate the in vivo removal of saliva into gastrointestinal tract by swallowing and salivary refreshment.

It has been shown that leached residual MMA reduced when the polymerization temperature and time were increased ${ }^{10,12,32}$, depending on the decreased residual MMA content ${ }^{21,29}$. In the present study, the use of terminal boiling produced marked reductions in $[\mathrm{MMA}]_{\mathrm{r}}$ of eluates. The results of previous studies $10,12,14,25,32$ that reported the reduction in residual monomer content with increased terminal boiling time supports the present finding of differences in [MMA], between long-term (H3) and short-term ( $\mathrm{H} 2$ and $\mathrm{H} 4)$ terminal boiling cycles. An another interesting finding was that leached $[\mathrm{MMA}]_{\mathrm{r}}$ of the short polymerization cycle together with short-term terminal boiling ( $\mathrm{H} 4)$ were lower than the polymerization cycle with no terminal boiling ( $\mathrm{H} 1)$, observed after 1 and 2 days of elution. Present findings support the results of previous studies $3,5,12,14,25,32$ that indicate the use of a terminal boiling stage at least for $30 \mathrm{~min}$ in the heat-polymerization to minimize the leaching residual MMA.

In the present study, XTT assay was used for the cell proliferation measurements. The reasons for use of XTT assay are higher sensitivity, production of a water soluble dye that simplifies the analysis and provides faster determination than other methods. The use of soluble formazans, such as $\mathrm{XTT}$, has been suggested to eliminate the errorprone solubilization step which is required for the microculture tetrazolium assays which employ MTT6,9,27.

According to the ISO ${ }^{13}$ (1999) 10993-5 standard, the degree of cytotoxic effect is classified as noncytotoxic when cell proliferation is more than $75 \%$, slightly cytotoxic when 50 to $75 \%$, moderately cytotoxic when 25 to $50 \%$ and highly cytotoxic when less than $25 \%$. Use of a terminal boiling stage has been previously attributed to produce improved cytotoxicity due to reduced residual monomer levels ${ }^{15,18}$. The finding of negative correlation between leaching $[\mathrm{MMA}]_{\mathrm{r}}$ and cell proliferation values indicates that leaching residual MMA content affects in vitro cytotoxicity of heat-polymerized acrylic resin. Within the polymerization cycles 
tested, the non-cytotoxic effect (the highest cell proliferation values) was determined in the cycles with short- $(\mathrm{H} 2)$ and long-term ( $\mathrm{H} 3)$ terminal boiling. However, this trend was observed at some elution periods and the degree of cytotoxicity produced by all the polymerization cycles tested was counted as slightly cytotoxic on L-929 fibroblasts at elution of 7 days. A previous study ${ }^{1}$ has reported higher cell survival rates of $92 \%, 82 \%, 83 \% 91 \%$ and $92 \%$ for heat-polymerized specimens after elution of 1 h, 1, 3, 5 and 7 days, respectively. The differences in cytotoxicity levels might be due to differences in the experimental designs, such as elution conditions or cell proliferation assay.

In vitro cytotoxicity of denture base acrylic resins were previously described mostly after 1 to 2 days of elution $7,8,16-19,22,23$. There are also few studies ${ }^{1,11,24,28,30}$ that investigated the in vitro cytotoxicity of denture base materials eluted for longer periods than 2 days of elution. In the present study, the shortest experimental period was 1 day for elution. The main reason for choosing this period was that the ISO $^{13}$ (1999) 10993-5 standard recommends a minimum of $24 \mathrm{~h}$ for elution (extraction) process. There is only one report ${ }^{1}$ of elution for $1 \mathrm{~h}$ of denture base acrylic resins. However measurement of earlier periods might provide additional scientific data about leaching mechanism of residual components and in vitro cytotoxic effects of denture base acrylic resins.

It is important to note that the non-significant changes in [MMA $]_{\mathrm{r}}$ (except $\mathrm{H} 3$ ) between elution of 5 and 7 days might be explained by a possible delayed or resistant leaching behavior of residual MMA from heat-polymerizing denture base acrylic resin ${ }^{2}$. After elution of 1 and 2 days, leached [MMA] of this polymerization cycle was also the lowest. In addition, the decreasing trend in cell proliferation values throughout days 5 and 7 might be due to the increasing trend in $[\mathrm{MMA}]_{\mathrm{r}}$ on the same days. For elution of 5 and 7 days, the lowest cytotoxic effect was observed in long-term polymerization cycle with short-term terminal boiling $(\mathrm{H} 2)$. Although no significant change in $[\mathrm{MMA}]_{\mathrm{r}}$ and cell proliferation values of this polymerization cycle was observed between the elution periods, this cycle has produced the lowest leaching [MMA], values and cytotoxic effect. The possibility of presenting $[\mathrm{MMA}]_{\mathrm{r}}$ values that clinically induce a toxic effect on oral mucosa or gastrointestinal tract seems to be low.

It has previously been stated that water storage of acrylic resin denture bases can lead to reduction of residual MMA by diffusion into water $5,18,29,31$. Based on the present findings of reduction of leaching $[\mathrm{MMA}]_{\mathrm{r}}$ into liquid cell culture media and slightly cytotoxic effects, water storage of at least 1 to 2 days can be recommended to minimize the risk potential of toxic or adverse effects of heat- polymerized prosthetic appliances.

The results from in vitro cytotoxicity tests cannot be directly applied to in vivo conditions. However, in vitro measures play an important role in the analysis of denture base acrylic resins. Testing of dental materials by cell culture methods is relatively simple to perform, reproducible, controllable and cost effective ${ }^{12}$. In vitro tests may provide vital information about the biological behavior of dental materials in a simplified system that minimizes the effect of confounding variables. The results of cytotoxicity tests have limitations with regard to their applicability to their clinical use. The materials used in dentures are subjected to changes in the moist environments of the oral cavity ${ }^{18}$. Therefore, findings of in vitro or in vivo tests cannot be extrapolated to the clinical setting ${ }^{15}$.

Further studies should focus on the identification of the leaching components or their derivatives in the moist environment. The correlation between leaching components and their effects on different cellular mechanisms may be interesting topics of future investigations.

\section{CONCLUSION}

Under the experimental protocol and within the limitations of this in vitro study, it can be concluded for heat-polymerized denture base acrylic resin:

- Residual MMA leached into cell culture media.

- Polymerization temperature and time can affect the leaching concentrations of residual MMA.

- Residual MMA continued to leach throughout 7 days of elution periods and leaching concentrations markedly reduced after elution of 1 and 2 days

- Reduction in residual MMA results in reduced in vitro cytotoxicity.

- The choice of a polymerization cycle with at least 30 min of terminal boiling may minimize the leached residual MMA and in vitro cytotoxicity.

\section{ACKNOWLEDGEMENTS}

This study was supported by The Research Support Unit of Istanbul University as the project no T-412/08032004.

\section{REFERENCES}

1- Ata SO, Yavuzyilmaz H. In vitro comparison of the cytotoxicity of acetal resin, heat-polymerized resin, and auto-polymerized resin as denture base materials. J Biomed Mater Res B Appl Biomater. 2009;91:905-9.

2- Austin AT, Basker RM. The level of residual monomer in acrylic denture base materials with particular reference to a modified method of analysis. Br Dent J. 1980;149:281-6.

3- Austin AT, Basker RM. Residual monomer levels in denture bases. The effects of varying short curing cycles. Br Dent J. $1982 ; 153: 424-6$. 
4- Baker S, Brooks SC, Walker DM. The release of residual monomeric methyl methacrylate from acrylic appliances in the human mouth: an assay for monomer in saliva. J Dent Res. 1988;67:1295-9.

5- Bayraktar G, Guvener B, Bural C, Uresin Y. Influence of polymerization method, curing process, and length of time of storage in water on the residual methyl methacrylate content in dental acrylic resins. J Biomed Mater Res B Appl Biomater. 2006;76:340-5.

6- Bean TA, Zhuang WC, Tong PY, Eick JD, Chappelow CC, Yourtee DM. Comparison of tetrazolium colorimetric and $51 \mathrm{Cr}$ release assays for cytotoxicity determination of dental biomaterials. Dent Mater. 1995;11:327-31.

7- Bouillaguet S, Shaw L, Gonzalez L, Wataha JC, Krejci I. Longterm cytotoxicity of resin-based dental restorative materials. J Oral Rehabil. 2002;29:7-13.

8- Cimpan MR, Cressey LI, Skaug N, Halstensen A, Lie SA, Gjertsen $B T$, et al. Patterns of cell death induced by eluates from denture base acrylic resins in U-937 human monoblastoid cells. Eur J Oral Sci. 2000;108:59-69.

9- Goodwin CJ, Holt SJ, Downes S, Marshall NJ. Microculture tetrazolium assays: a comparison between two new tetrazolium salts, XTT and MTS. J Immunol Methods. 1995;13;179:95-103. 10- Honorez P, Catalan A, Angnes U, Grimonster J. The effect of three processing cycles on some physical and chemical properties of a heat-cured acrylic resin. J Prosthet Dent. 1989;61:510-7.

11- Huang FM, Tai KW, Hu CC, Chang YC. Cytotoxic effects of denture base materials on a permanent human oral epithelial cell line and on primary human oral fibroblasts in vitro. Int ] Prosthodont. 2001;14:439-43.

12- Huggett R, Brooks SC, Bates JF. The effect of different curing cycles on levels of residual monomer in acrylic resin denture base materials. Quintessence Dent Technol. 1984;8:365-71.

13- International Organization for Standardization. ISO 10993-5: biological evaluation of medical devices - Part 5: Tests for in vitro cytotoxicity. Geneva: ISO; 1999.

14- Jagger RG. Effect of the curing cycle on some properties of a polymethylmethacrylate denture base material. J Oral Rehabil. 1978; 5:151-7.

15- Jorge JH, Giampaolo ET, Machado AL, Vergani CE. Cytotoxicity of denture base acrylic resins: a literature review. J Prosthet Dent. 2003;90:190-3.

16- Jorge JH, Giampaolo ET, Vergani CE, Machado AL, Pavarina AC, Carlos IZ. Biocompatibility of denture base acrylic resins evaluated in culture of $\mathrm{L} 929$ cells. Effect of polymerisation cycle and postpolymerisation treatments. Gerodontology. 2007;24:52-7.

17- Jorge JH, Giampaolo ET, Vergani CE, Machado AL, Pavarina AC, Carlos IZ. Cytotoxicity of denture base resins: effect of water bath and microwave postpolymerization heat treatments. Int J Prosthodont. 2004;17:340-4.
18- Jorge JH, Giampaolo ET, Vergani CE, Machado AL, Pavarina AC, Carlos IZ. Effect of post-polymerization heat treatments on the cytotoxicity of two denture base acrylic resins. J Appl Oral Sci. 2006;14:203-7.

19- Jorge JH, Giampaolo ET, Vergani CE, Pavarina AC, Machado $A L$, Carlos IZ. Effect of microwave postpolymerization treatment and of storage time in water on the cytotoxicity of denture base and reline acrylic resins. Quintessence Int. 2009;40:e93-100. 20- Koda T, Tsuchiya H, Yamauchi M, Hoshino Y, Takagi N, Kawano J. High-performance liquid chromatographic estimation of eluates from denture base polymers. J Dent. 1989;17:84-9.

21- Koda T, Tsuchiya H, Yamauchi M, Ohtani S, Takagi N, Kawano J. Leachability of denture-base acrylic resins in artificial saliva. Dent Mater. 1990;6:13-6.

22- Lefebvre CA, Knoernschild KL, Schuster GS. Cytotoxicity of eluates from light-polymerized denture base resins. J Prosthet Dent. $1994 ; 72: 644-50$.

23- Lefebvre CA, Schuster GS. Biocompatibility of visible light-cured resin systems in prosthodontics. J Prosthet Dent. $1994 ; 71: 178-85$.

24- Lefebvre CA, Schuster GS, Marr JC, Knoernschild KL. The effect of $\mathrm{pH}$ on the cytotoxicity of eluates from denture base resins. Int J Prosthodont. 1995;8:122-8.

25- Lung CY, Darvell BW. Minimization of the inevitable residual monomer in denture base acrylic. Dent Mater. 2005;21:1119-28. 26- Phoenix RD. Denture base resins. In: Anusavice KJ, ed. Phillips' science of dental materials. $11^{\text {th }}$ ed. China: Saunders Elsevier; 2003. p:721-57

27- Roehm NW, Rodgers GH, Hatfield SM, Glasebrook AL. An improved colorimetric assay for cell proliferation and viability utilizing the tetrazolium salt XTT. J Immunol Methods. 1991;142:257-65.

28- Sheridan PJ, Koka S, Ewoldsen NO, Lefebvre CA, Lavin MT. Cytotoxicity of denture base resins. Int J Prosthodont. 1997;10:737.

29- Stafford GD, Brooks SC. The loss of residual monomer from acrylic orthodontic resins. Dent Mater. 1985;1:135-48.

30- Tsuchiya $\mathrm{H}$, Hoshino $\mathrm{Y}$, Tajima K, Takagi N. Leaching and cytotoxicity of formaldehyde and methyl methacrylate from acrylic resin denture base materials. J Prosthet Dent. 1994;71:618-24. 31- Vallittu PK, Miettinen V, Alakuijala P. Residual monomer content and its release into water from denture base materials. Dent Mater. 1995;11:338-42.

32- Vallittu PK, Ruyter IE, Buykuilmaz S. Effect of polymerization temperature and time on the residual monomer content of denture base polymers. Eur J Oral Sci. 1998;106:588-93. 